\title{
Author Correction: A consensus-based transparency checklist
}

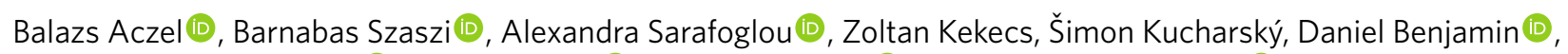

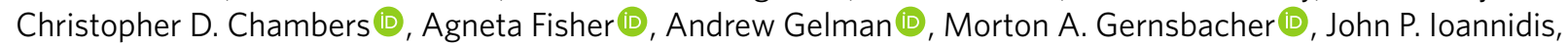
Eric Johnson (10, Kai Jonas (D), Stavroula Kousta, Scott O. Lilienfeld, D. Stephen Lindsay, Candice C. Morey (1D,

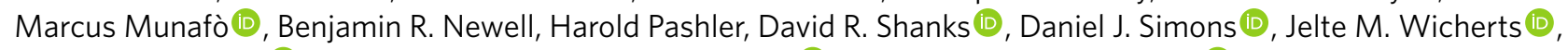
Dolores Albarracin (D), Nicole D. Anderson, John Antonakis (D), Hal R. Arkes, Mitja D. Back (D), George C. Banks,

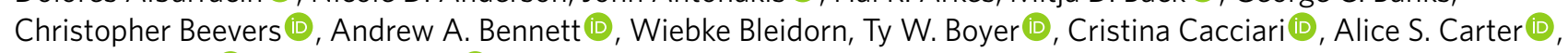
Joseph Cesario (1), Charles Clifton (D), Ronán M. Conroy, Mike Cortese, Fiammetta Cosci, Nelson Cowan, Jarret Crawford, Eveline A. Crone, John Curtin (1D, Randall Engle, Simon Farrell, Pasco Fearon, Mark Fichman (D, Willem Frankenhuis,

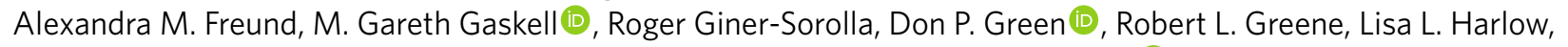
Fernando Hoces de la Guardia, Derek Isaacowitz, Janet Kolodner, Debra Lieberman (D), Gordon D. Logan, Wendy B. Mendes (D), Lea Moersdorf, Brendan Nyhan, Jeffrey Pollack (D), Christopher Sullivan (D), Simine Vazire (1) and Eric-Jan Wagenmakers (i)

Correction to: Nature Human Behaviour https://doi.org/10.1038/s41562-019-0772-6, published online 2 December 2019.

In the version of this article initially published, the surname of author Marcus Munafò was misspelled. The error has been corrected in the HTML and PDF versions of the article.

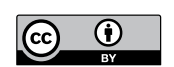

Open Access This article is licensed under a Creative Commons Attribution 4.0 International License, which permits use, sharing, adaptation, distribution and reproduction in any medium or format, as long as you give appropriate credit to the original author(s) and the source, provide a link to the Creative Commons license, and indicate if changes were made. The images or other third party material in this article are included in the article's Creative Commons license, unless indicated otherwise in a credit line to the material. If material is not included in the article's Creative Commons license and your intended use is not permitted by statutory regulation or exceeds the permitted use, you will need to obtain permission directly from the copyright holder. To view a copy of this license, visit http://creativecommons.org/licenses/by/4.0/.

Published online: 23 December 2019

https://doi.org/10.1038/s41562-019-0812-2

(c) The Author(s) 2019 